\title{
Zuzanna Krasnopolska
}

\section{WICEKRóLOWIE: bezlitosna autobiografia narodu włoskiego}

\author{
Chcę wytłumaczyć, jak rodzina, mała grupa \\ żywych istot, zachowuje się w społeczeństwie \\ rosnąc i wydając na świat dziesięć do \\ dwudziestu jednostek, które z początku \\ wyglądają, jakby były całkowicie różne jedna \\ od drugiej, przy bliższej obserwacji wszakże \\ zdradzają bardzo ścisłe związki między sobą. \\ Dziedziczność ma swoje prawa tak jak ciążenie
}

(Emil Zola ${ }^{1}$ ).

„To trudna książka, która nie oświeca umysłu, ani nie porusza serca” (Benedetto Croce), „to druga, po Narzeczonych, najważniejsza włoska powieść XIX wieku" (Leonardo Sciascia) - Wicekrólowie (I viceré, 1894, tłum. polskie Zofii Ernstowej, 1995) pióra Federica De Roberta od zawsze wzbudzali krańcowo różne opi$n^{2}{ }^{2}$. Pisarz nie był ani za życia, ani po swojej śmierci ulubieńcem publiczności i krytyki. We Włoszech trzeba było czekać do lat

${ }^{1}$ Emil Zola, Pochodzenie rodziny Rougon-Macquartów (przedmowa), tłum. Krystyna Dolatowska, Warszawa: Państwowy Instytut Wydawniczy 1956, s. 5.

${ }^{2}$ Druzgocąca krytyka Crocego, która po raz pierwszy ukazała się na łamach „La Critica” z roku 1939, została później opublikowana w Letteratura della nuova Italia, vol. VI, Bari: Laterza 1940 s. 139-152. Natomiast pochwała pióra Sciasci pochodzi z jego eseju z 1978 roku, opublikowanego po raz pierwszy na łamach „Corriere della Sera” w 1999 roku z okazji dwudziestej rocznicy śmierci sycylijskiego pisarza. Zob. Matteo Collura, Leonardo Sciascia, L'inguaribile Sicilia dei gattopardi, „Corriere della Sera”, 2.11.1999. 
sześćdziesiątych ubiegłego stulecia, aby dzięki publikacji Gepar$d a^{3}$ Tomasiego di Lampedusy (1957) powrócono do dyskusji na temat powieści historycznej, a w konsekwencji, by odrodziło się zainteresowanie twórczością De Roberta. Poza granicami swojej ojczyzny pisarz jest jednak nadal mało znany, nawet wśród italianistów.

Urodzony w Neapolu w 1861 roku, ale uważany za Sycylijczyka (większość swojego życia spędził w Katanii), Federico De Roberto należał do kręgu pisarzy skupiających się wokół Giovanniego Vergi, twórcy weryzmu. Chcąc oddać hołd swojemu mistrzowi i przyjacielowi, De Roberto stworzył trylogię mającą stanowić kontynuację przerwanego cyklu Zwyciężeni (I vinti) Vergi, którego projekt objął tylko najniższe warstwy społeczeństwa w Rodzinie Malavogliów (I Malavoglia, 1881) oraz rodzącą się klasę średnią w Mastro don Gesualdo (1889). Wicekrólowie, wraz z wcześniejszą powieścią Złudzenie (L'Illusione, 1891, tłum. polskie anonimowe, 1905) oraz ostatnią, niedokończoną i wydaną pośmiertnie L'Imperio (1929) przedstawiają świat arystokracji. Jednak tak, jak pierwsza i trzecia część trylogii opisuje głównie losy jednego z członków rodu Uzeda, Wicekrólowie to portret zbiorowy całej sycylijskiej rodziny Uzeda di Francalanza, potomków wicekrólów (czyli królewskich urzędników, namiestników) hiszpańskich.

Powieść rozpoczyna się in medias res: właśnie zmarła głowa rodu Uzeda - księżniczka Teresa - i cała rodzina zjeżdża się do jej posiadłości, aby uczestniczyć w pogrzebie oraz, co okaże się najważniejsze, być obecnym podczas odczytania jej testamentu. W tej chwili oczekiwania wychodzą na jaw wszystkie wzajemne niesnaski, pretensje, nasilają się trwające od lat konflikty, nie ustają od dawna snute intrygi. De Roberto kreśli portrety bohaterów przy

${ }^{3}$ W nowym tłumaczeniu Stanisława Kasprzysiaka Gattopardo to Gepard (Giuseppe Tomasi di Lampedusa, Gepard, Warszawa: Czuły Barbarzyńca Press 2009), a nie, jak wcześniej u Zofii Ernstowej, Lampart. Swoją decyzję tłumacz argumentuje w posłowiu, s. 318-321. 
użyciu fokalizacji wewnętrznej: to z perspektywy dona Blaski zostaje czytelnikowi zaprezentowana cała ta zbieranina postaci i typów charakterologicznych. Oto przed nami bracia męża zmarłej: don Gaspare (diuk d'Oragua i przyszły oportunistyczny polityk), wspomniany już benedyktyn don Blasco (bluźnierczy, rozpustny, chciwy i obojętny na to, co o nim myślą inni), don Eugenio (żałosny grafoman, który z braku funduszy sprzedaje fałszywe drzewa genealogiczne i herby) i donna Ferdinanda (zgorzkniała, złośliwa stara panna parająca się lichwą). Następnie, dorosłe już dzieci księżniczki: książę Giacomo (despotyczny i zabobonny pierworodny syn znienawidzony przez matkę, zresztą z wzajemnością) z żoną Margheritą, don Raimondo (oczko w głowie matki, bawidamek i lekkoduch) z żoną Matildą, don Lodovico (oddany do zakonu wbrew własnej woli, obecnie kardynał), don Ferdinando, zwany il Babbeo, „Głupim” (opóźniony w rozwoju, żyjący na wzór Robinsona Kruzoe), donna Chiara (zmuszona do poślubienia niekochanego markiza Federica di Villardita) i donna Lucrezia (przeznaczona do staropanieństwa, dopiero po śmierci matki poślubi Benedetta Giuliana, adwokata, a zatem pochodzącego z niższego stanu, ale ukochanego i sprzyjającego rodzinie nowego burmistrza Katanii). Dalej, dzieci pierworodnego księcia Giacomo: Consalvo (przyszły polityk) i Teresa (porzucająca Giovanniego, aby zgodnie z wolą ojca poślubić lo Scorpio, „Skorpiona”, brzydkiego, ale starszego, więc i dziedziczącego brata swojego ukochanego). Losy każdej postaci podporządkowane są legge del maggiorasco, czyli „prawu majoratu”, które uniemożliwiało dzielenie majątku, dziedziczonego tylko przez pierworodnego syna; młodsi bracia mieli do wyboru drogę urzędniczą lub kościelną, niezamężne siostry zaś - zakon lub staropanieństwo. Wraz z powstaniem państwa włoskiego oraz powołaniem parlamentu pojawiła się trzecia możliwość - polityka - i właśnie z tej opcji skorzystają don Gaspare i Consalvo. Ich losy pokazują, że na pewnym etapie historii, to władza stała się najsilniejszym atutem, ważniejszym nawet od pieniędzy. 
De Roberto tworzy powieść niezwykle bogatą, wielowątkową i polifoniczną, stopniowo ujawniając czytelnikowi szaleństwa, degeneracje, patologie, dziwactwa oraz megalomanię każdego z członków rodziny Uzeda, którą anonimowy tłum nazywa często „brzydką rasą” i „rasą szaleńców”4. Nie oszczędza nikogo: mężczyznom zarzuca głównie despotyzm, transformizm polityczny, przedkładanie nade wszystko własnego interesu, zawiść, zazdrość, zakłamanie i pychę. U każdego z bohaterów obnaża jego małośći okrucieństwo: książę Giacomo tyranizuje całą rodzinę i szantażuje brata, don Raimondo porzuca żonę z dwójką małych dzieci, mnich don Blasco pozostaje w związku z żoną innego mężczyzny, a don Gaspare zmienia orientacje polityczne jak rękawiczki. Ta bezlitosna analiza ludzkich charakterów nie omija również kobiet. Zarzucona im zostaje pasywność, masochizm i histeria: donna Lucrezia oraz donna Chiara przechodzą z nienawiści w miłość i z miłości do nienawiści wobec własnych mężów w sposób prawie schizofreniczny, donna Matilde czerpie wręcz duchową przyjemność z bycia oszukiwaną i zdradzaną przez męża, a kuzynka donna Graziella, pod płaszczykiem religijności, kryje przebiegły charakter. Nawet Teresa, słodka i niewinna siostra Consalva, nie jest bez winy - jej dobroć, łatwowierność i pobożność (Teresa stawia sobie za wzór świętą Xymenę, która poślubiła niekochanego mężczyznę, a Bóg w nagrodę uczynił ją świętą) są nadmiernie przerysowane w takim samym stopniu, jak patologiczne i wszechobecne jest zło innych bohaterów.

Każdy z członków rodziny odziedziczył negatywne cechy charakteru po swoich przodkach, podobnie jak w cyklu Rougon-Maquartów Emila Zoli. Jednak De Roberto poprzez swoją opowieść o losach jednej rodziny przedstawia również historię narodową lat 1855-1882, trudną drogę od reżimu Burbonów do nowych realiów politycznych: upadku Królestwa Obojga Sycylii, burzliwego zjed-

${ }^{4}$ Federico De Roberto, I viceré, [w:] Romanzi, novelle e saggi, Milano: Mondadori 2004, s. 683 i 417. Cytowane fragmenty książek oraz dialogi filmowe - jeżeli nie zaznaczono tego inaczej - w tłumaczeniu Z. K. 
noczenia Włoch (Risorgimento) i powstania transformizmu politycznego ${ }^{5}$ : Za czasów wicekrólów, nasi byli wicekrólami. Teraz, gdy mamy Parlament, wujek jest posłem! Wśród bohaterów pobocznych pojawiają się postaci historyczne, takie jak Giuseppe Garibaldi, Nino Bixio oraz Giuseppe Menotti. Tym samym książka staje się nie tylko powieścią o obyczajach, jak u Zoli, czy też powieścią psychologiczną, ale przede wszystkim powieścią historyczną, dodatkowo rewolucjonizującą ten gatunek we Włoszech - romantyczny i idealizowany obraz pełnego bohaterstwa Risorgimento zostaje tu pokazany w krzywym zwierciadle 6 .

Wizerunek Włoch wyłaniający się ze stron Wicekrólów jest ironiczny, gorzki, pesymistyczny i nad wyraz współczesny. Nic więc dziwnego, że próby przeniesienia tej powieści na ekran trwały od dłuższego czasu. Z projektu rezygnowali tacy reżyserzy, jak Luchino Visconti czy Roberto Rossellini. Scenarzyści pracujący dla włoskiej telewizji publicznej Rai, w tym Sandro Bolchi i Lucio Mandarà w latach osiemdziesiątych oraz Ugo Pirro, Massimo Russo i Aida Mangia w latach dziewięćdziesiątych, musieli wycofać się z już prawie gotowego projektu; ci pierwsi z powodu cenzury polityczno-religijnospołecznej (Watykan uznał powieść De Roberta za obrazoburczą), ci drudzy - z braku funduszy.

W 2007 roku Roberto Faenza wraz z Franceskiem Bruni (scenarzystą filmów Paola Virzì i serialu o komisarzu Montalbano)

${ }^{5}$ Transformizm polityczny, trasformismo - sposób prowadzenia polityki, opierający się na oportunistycznym i niekonsekwentnym zachowaniu, tj. na porzuceniu zasad i idei, które wyznawało się wcześniej na rzecz innych, bardziej sprzyjających w nowych warunkach. Innymi słowy, opiera się na zamazaniu różnic pomiędzy większością a opozycją, połączeniu prawicy z lewicą liberalną i stworzeniu jednej partii centrum, charakteryzującej się silnie rozwiniętym systemem klientalnym. Włoski transformizm polityczny zapoczątkował w 1882 roku Agostino Depretis z lewicy (tzw. historycznej), poszerzając swoją większość parlamentarną polityków konserwatywnych w celu zablokowania jakiejkolwiek reformy polityków postępowych.

${ }^{6}$ Margherita Ganeri, L'Europa in Sicilia. Saggi su Federico De Roberto, Firenze: Le Monnier Università 2004, s. 62. 
zdecydował się zmierzyć z Wicekrólami i przy konsultacji historyczno-literackiej jednego z największych współczesnych znawców twórczości De Roberta, profesora Antonia Di Grado z Uniwersytetu w Katanii, stworzył scenariusz i wyreżyserował film, współfinansowany przez Rai. Tym samym, zarzuty stawiane Faenzy przez niektórych krytyków filmowych (m.in. Paola Mereghettiego na łamach „Corriere della Sera”) dotyczące przypisywania bohaterom kontrowersyjnych słów, które jakoby nie były autorstwa De Roberta - wydają się bezpodstawne ${ }^{7}$ (do tego stwierdzenia powrócę jeszcze za chwilę).

Roberto Faenza, urodzony w Turynie w 1943 roku, zadebiutował filmem ESKALACJA (Escalation, 1968). W twórczości tego reżysera i scenarzysty można zauważyć swego rodzaju dwutorowość: $\mathrm{z}$ jednej strony mamy do czynienia z wyraźnym zaangażowaniem politycznym (Forza ITALIA, 1978, film dokumentalny ostro krytykujący Chrześcijańską Demokrację), z drugiej - kino dramatycznosentymentalne (PRENDIMI L'ANIMA, 2002, GIORNI DELL'ABBANDONO, 2005). Faenza znany jest polskiej publiczności głównie z ostatniego filmu Marcella Mastroianniego TwIERdZI PEREIRA (Sostiene Pereira, 1996) oraz z adaptacji powieści Dacii Maraini zatytułowanej Długie życie Marianny Ucrìa (MARIANNA UCRÌA, 1997).

W głównych rolach reżyser obsadził dzisiejsze i minione gwiazdy teatru (pozostając tym samym wiernym epickości opowieści) oraz kina włoskiego i hiszpańskiego (tak jak włosko-hiszpańskie są korzenie rodziny Uzeda!), zwabiając tym samym do kin zarówno młode, jak i starsze pokolenie. W roli Consalva - Alessandro Preziosi, aktor teatralny, kinowy i telewizyjny, znany polskiemu widzowi z serialu Elisa z Rivombrosy (Elisa di Rivombrosa, 2002-2005, reż. Cinzia Torrini i Stefano Alleva) i z najnowszego filmu Ferzana

${ }^{7}$ Por. Paolo Mereghetti, Dopo tante polemiche Faenza delude. Non c'è la sottigliezza di De Roberto, „Corriere della Sera”, 9.11.2007. Odpowiedź Antonia Di Grado na forum Uniwersytetu w Katanii: www.ivicere.it/news/news34.html (10.10.2010). 
Ozpeteka MiŁość z MAKARONEM W TLE (Mine vaganti, 2010); w roli Teresy - aktorka młodego pokolenia Cristina Capotondi, która zdobyła popularność dzięki przebojowi kasowemu Noc PRZED EGZAMINAMI (Notte prima degli esami, 2006, reż. Fausto Brizzi). W roli don Giacoma - Lando Buzzanca, Sycylijczyk debiutujący w 1961 roku w Rozwodzie po wŁosku (Divorzio allitaliana, 1961, reż. Pietro Germi), aktor o bogatym repertuarze kinowo-telewizyjnym; w rolach wujów - aktorzy teatralni znani ze swoich interpretacji m.in. Szekspira i Pirandella: Sebastiano Lo Monaco (don Gaspare), Franco Branciaroli (don Raimondo) oraz Hiszpan Pep Cruz (don Blasco); jako ciotka Ferdinanda - Lucia Bosè, rówieśniczka Giny Lollobrigidy, gwiazda kina włoskiego i hiszpańskiego; w drugoplanowej roli matki Giovanniego - Assumpta Serna, znana z Matadora (1986, reż. Pedro Almodovar). Wśród obsady jest też akcent polski - donnę Isabellę, kochankę don Raimonda, zagrała polska aktorka często pojawiająca się we włoskiej telewizji, Magdalena Grochowska.

W trakcie realizacji WicEKRóLów, Roberto Faenza zgromadził wokół siebie zespół często z nim współpracujących twórców, takich jak Massimo Fiocchi (montaż) i Maurizio Calvesi (zdjęcia). Oprócz nich, w pracach nad filmem uczestniczyli: kompozytor Paolo Buonvino (autor ścieżki dźwiękowej do największych sukcesów m.in. Gabriela Muchino, często współpracujący z piosenkarką Carmen Consoli), znakomita projektantka kostiumów Milena Canonero oraz scenograf Francesco Frigeri (twórca scenografii do filmów w reżyserii m.in. Giuseppe Tornatore). Zdjęcia kręcono w Katanii oraz w pałacu Chigi w Ariccia, gdzie przed laty Luchino Visconti filmował swojego LAMPARTA (Il gattopardo, 1963). Obecność Viscontiego nie objawia się jednak jedynie poprzez wykorzystanie tego samego miejsca akcji - w wizji Faenzy można wyczuć chęć dorównania mistrzowi, przede wszystkim podczas sceny balu, która zdaje się być wzorowana na bodajże najsłynniejszej scenie ekranizacji dzieła Tomasiego di Lampedusy.

Oczywiste jest, że filmowa adaptacja siedmiusetstronicowej powieści wymaga wprowadzenia niezbędnych skrótów w fabule 
i dokonania koniecznych wyborów wśród występujących w niej wątków i bohaterów (pominięte zostały postaci poboczne, jak don Eugenio i don Ferdinando). Zresztą Faenza dokładnie określił swoją wizję adaptacji już w napisach tytułowych, precyzując, że film jest jedynie „swobodnie zainspirowany książką”.

W ekranizacji historia opowiedziana jest z punktu widzenia narratora Consalva, co powoduje, że układa się ona w swoisty Bildungsroman głównego bohatera. Ten wybór pociągnął za sobą rozbudowanie drugiej połowy II i całej III części powieści oraz streszczenie I części tylko w paru scenach. Faenza oparł swój portret Consalva przede wszystkim na konflikcie syna z ojcem, nakreślonym o wiele wyraźniej niż w oryginalnym tekście. Nawet scena otwierająca film nie przedstawia wcale zamieszania po śmierci księżniczki Teresy, ale młodego Consalva karanego przez ojca. Główny bohater od małego obserwuje otaczającą go rzeczywistość, wpierw niewinnie zakrada się na strych i podgląda przez szpary między deskami, zza krzaków bądź przez dziurkę od klucza - złapany na gorącym uczynku usprawiedliwia się chęcią poszukiwania prawdy. I tak, widz wraz z Consalvem odkrywa zdradę don Raimonda i jego związek z Isabellą; to z nim podgląda zmarłe zdeformowane dziecko Chiary w słoiku z formaliną oraz zainscenizowane przez Chiarę intymne spotkanie jej męża ze służącą Rosą i narodziny dziecka, które potem zaadoptowała; to głównemu bohaterowi Giovannino pokazuje rozwiązłość i hipokryzję mnichów benedyktynów, w tym dona Blaski. Jako dorosły mężczyzna, rozczarowany Consalvo stopniowo rezygnuje z dziecinnego i naiwnego marzenia o wiecznym poszukiwaniu prawdy.

Zdając sobie sprawę z zakłamania i panującego wokół fałszu, młody książę odcina się od ojca, uosabiającego w jego rozumieniu całe zło. Prowadzi z nim wręcz otwartą wojnę, nie widząc przy tym, że rodzący się w nim despotyzm i bezwzględność coraz bardziej upodabniają go do znienawidzonego rodzica. Po dowcipnej uwadze siostry zapuściłeś wąsy, takie jakie ma nasz tata! goli je - ale i to, oczywiście, nie wystarcza, aby się od niego na stałe odciąć 
i odróżnić. Apogeum ich konfliktu następuje jednak wiele lat później, w nocy, kiedy to umiera matka Consalva i Teresy. Tuż przed jej śmiercią, syn widzi ojca w niedwuznacznej sytuacji z kuzynką Graziellą. Nazajutrz, po nieoficjalnej zapowiedzi zaręczyn księcia Giacomo z kuzynką, Consalvo zrywa wszelkie kontakty z ojcem.

0 ile w książce wszechwiedzący narrator odcina się od przekonań i zachowań Consalva (będącego dla niego tylko jednym $\mathrm{z}$ wielu zdeprawowanych przedstawicieli rodu Uzeda), o tyle w filmie bywa on momentami postacią wręcz pozytywną i wzbudzającą sympatię. W sposób dyplomatyczny wycisza samobójstwo Giovanniego, który strzela sobie w skroń po ślubie ukochanej Teresy z innym. Consalvo doskonale zdaje sobie sprawę ze zła panoszącego się $\mathrm{w}$ jego rodzinie. W jednym ze swoich monologów, stwierdza wręcz, że nasza rasa nie jest zdegenerowana - ona jest zawsze taka sama, jakby doskonale wiedział, że zakłamanie, fałsz i patologia są jej nieodzowną częścią. Motorem działań rodu Uzeda pozostaje od lat nienawiść. Don Giacomo daje swego rodzaju lekcję życia małemu Tancrediemu, przybranemu synowi donny Chiary: Tu wszyscy mnie nienawidzą. Sam nauczyłem ich nienawiści do mnie. To właśnie nienawiść nas umacnia, nie miłość, jak mówiq ludzie słabi, to nienawiść trzyma nas przy życiu.

Tym samym transformizm polityczny Consalva można też uznać, w pewnym sensie, za dziedziczny. $Z$ początku, rozmawiając z don Gaspare o jego orientacji politycznej, dziecinnie zapytywał: Przepraszam, wuju, wybaczcie mi. Ale wy jesteście z prawicy, prawda? A premier nie jest $z$ lewicy? Jakże jednoznaczna i cyniczna była odpowiedź polityka: Drogi Consalvo, ale ciebie to naprawdę niczego nie nauczyli! Prawica, lewica, nie oznaczaja dziś nic! W naszych czasach wszystko zmienia się $w$ takim tempie, że nie możemy trzymać się sztywno etykietek. Czyż takie podejście do polityki nie jest też charakterystyczne dla naszych czasów? Ta wymiana zdań między Consalvem a jego wujem nie jest jedyną złotą myślą De Roberta, którą słyszymy w filmie - w adaptacji Faenzy to książę Giacomo jest autorem gorzkiej parafrazy patriotycznego hasła Massima d'Aze- 
glio, jednego z twórców włoskiego Risorgimento („zrobiliśmy Włochy, a teraz musimy zrobić Włochów"): zrobiliśmy Włochy, a teraz zajmijmy się naszymi sprawami oraz spostrzeżenia wolność to słowo, które nie oznacza nic, a zadowala wszystkich. Ma rację Ernesto Galli della Loggia, twierdząc, że w Wicekrólach tkwi „antropologia włoskiej polityki: (...) nienasycenie, nieunikniona hipokryzja obyczajów i, na samo zakończenie, decydująca rola "przyjaciół«"”.

Dopiero po samobójstwie przyjaciela Giovanniego (aby nie skończyć tak, jak on, trzeba być bezwzględnym) oraz po śmierci ojca, Consalvo porzuca swoją naiwność i chęć odnalezienia za wszelką cenę prawdy, dostosowując się do realiów politycznych. Świadectwem tej zmiany jest jego płomienna przemowa, jako kandydata w wyborach na burmistrza Katanii w roku 1882 (w tej roli zastąpił przepełnionego ideałami męża swojej ciotki, adwokata Giuliente). Consalvo, choć na początku, wzorując się na książkach lewicujących autorów, zamierzał zgromadzić wokół siebie przedstawicieli najniższych warstw społecznych, o których nikt nie pamiętał, i o których głosy nikt nigdy nie zabiegał, w końcu zwrócił się ku elektoratowi bliższemu mu społecznie, czyli do zwolenników papieża i Garibaldiego: dwóch środowisk tak różnych, jak diabeł i woda święcona. W przemowie, aby przeciągnąć na swoją stronę te dwie skłócone frakcje, wspomniał chwilę, w której jakoby widział modlącego się Garibaldiego - Garibaldiego, o którym wszyscy wiedzieli, że był antyklerykałem! W istocie, Consalvo chciał stworzyć rodzaj bezideowej i utopijnej partii, która łączyłaby w sobie wszystkie sprzeczności, była wszystkim a jednocześnie niczym, która ochroniłaby laików, ale również Kościót, która realizowałaby reformy, ale i strzegłaby tradycji (...) Niech żyje król! Niech żyje rewolucja! Niech żyje Jego Świątobliwość!

Nie możemy jednak zapomnieć, że już na początku filmu, przy napisach tytułowych, ponadkadrowy głos Consalva informuje nas, że czuje (on) w sobie dziesięć, sto różnych osób, każdq oddzielnie, ale

\footnotetext{
${ }^{8}$ Ernesto Galli della Loggia, Calendario, „Corriere della Sera”, 29.07.2007.
} 
WICEKRóLOWIE: bezlitosna autobiografia narodu włoskiego

wspólnie, jak sobie przerywaja, zaprzeczajq, mieszajq się w wielkim zgiełku - co ciekawe, to zdanie nie występuje w Wicekrólach, ale jest obecne, w nieco odmiennej wersji, w Miłościach (Gli amori, 1898) De Roberta 9 . Te słowa, wprowadzone do scenariusza za radą Margherity Ganeri ${ }^{10}$, badaczki De Roberto, łączą przekonania bohatera i jego autora, którego cechami typowymi zarówno w życiu, jak i w twórczości był kameleonizm ${ }^{11}$. Ten sam sens ma ostatnia rozmowa Consalva z ciotką Ferdinandą: historia jest wyłącznie monotonną powtórka, ludzie byli, sq i będq zawsze ci sami. Obie wypowiedzi spinają klamrą początek i koniec filmu, którego myślą przewodnią jest przekonanie bohatera, że w zmieniającym się świecie konieczne jest przyjęcie nowych realiów, ale należy dostosować je do własnych potrzeb, nagiąć do własnych interesów. W pewnym stopniu możemy uznać, że synonimem transformizmu jest gepardyzm $^{12}$ Tomasiego di Lampedusy - oportunistyczna postawa polegająca na dostosowywaniu się do sytuacji. Tym samym opinia Consalva Uzedy pokrywa się w pewnym sensie ze słowami Tancrediego z Geparda: „jeśli chcemy, by wszystko zostało tak, jak jest, trzeba, by wszystko się zmieniło"13. Jedyna różnica między tymi dwiema

${ }^{9} \mathrm{~W}$ oryginale te słowa, $\mathrm{w}$ nieco odmiennym brzmieniu, wypowiada kobieta: „Czuję w sobie dziesięć, sto różnych kobiet, wielość istnień, z których każde chciałoby działać na swój sposób, a najdziwniejsze jest to, że mówią po kolei i jednocześnie, przerywając sobie, zaprzeczając, mieszając się w zgiełku”, Federico De Roberto, Lettere di commiato, [w:] idem, Gli amori, Milano: Galli 1898, s. 255.

${ }^{10}$ Margherita Ganeri, Il ritorno dei Viceré grazie a Faenza, www.ivicere.it (10.10.2010).

${ }^{11}$ Kameleonizm, transformizm czy wręcz transwestytyzm to cechy charakterystyczne dla pisarstwa De Roberta. Brak jednolitego stylu, różnorodna twórczość oraz zmiana w ocenie bohaterów (np. przejście od całkowitego mizoginizmu do identyfikacji z bohaterką Złudzenia) sprawiają, że często trudno uwierzyć, że wszystkie teksty zostały napisane przez tego samego autora. Por. Margherita Ganeri, op. cit., s. 7-22.

${ }^{12}$ W związku z nowym tłumaczeniem Stanisława Kasprzysiaka (Gattopardo jako Gepard) gattopardismo to gepardyzm. Zob. też przyp. 3.

${ }^{13}$ Giuseppe Tomasi di Lampedusa, op. cit., s. 28. 
myślami sprowadza się, według Margherity Ganeri, do faktu, że w Gepardzie nie stanowi ona myśli przewodniej ${ }^{14}$. Książę Salinas zdaje sobie sprawę, że „wiek gepardów” mija razem z nim i że buńczuczny Tancredi nie miał racji: „byliśmy gepardami, lwami; ci co przyjdą po nas, będą szakalikami, hienami"15.

W tym miejscu nie można nie wspomnieć o Baldassarze, majordomusie rodziny Uzeda, bękarcie, przyrodnim bracie księcia Giacomo. W jego osobie Roberto Faenza wydobywa $\mathrm{z}$ oryginału powieściowego jeszcze jedną klamrę, spinającą tym razem nie początek i koniec filmu, ale początek i koniec pierwszego etapu życia Consalva Uzedy. To Baldassare czuwa nad małym księciem, gdy ten na klęczkach odbywa karę zadaną mu przez ojca na początku filmu; to z Baldassare podróżuje Consalvo do Rzymu, gdzie uczestniczy w pierwszej lekcji polityki u swego wuja Gaspare; to wreszcie Baldassare pomaga mu podczas kampanii wyborczej. Pod koniec filmu, gdy szczęśliwy tłum unosi na rękach nowo obranego burmistrza, księcia Uzedę, Baldassare udaje się w przeciwną stronę, przerzuca przez ramię marynarkę i zostawia Consalva. Ten ostatni „wybryk” panicza, ta zdrada własnych wartości, ta akceptacja przekonań, którymi wcześniej przecież gardził, jako typowymi dla swojego bezdusznego ojca, nie mogą zostać przyjęte przez kogoś, kto całe życie ufał w dobroć i prawość swojego wychowanka. Baldassare, niczym wcielenie sumienia historii, prawości i uczciwości, opuszcza Consalva i tym samym, w życiu głównego bohatera zaczyna się nowy rozdział.

Jego uwieńczeniem jest finałowa scena filmu, zapożyczona z ostatniej części trylogii De Roberta, L'Imperio. W dniu swoich siedemdziesiątych siódmych urodzin, 20 listopada 1918 roku, Consalvo czeka w pustym Parlamencie na pierwsze posiedzenie włoskiego zgromadzenia narodowego w nowej sali Montecitorio. Patrząc prosto w obiektyw kamery, bez zbędnej gestykulacji i emocji, opowiada o braku efektywności parlamentarnej, o zakłamaniu

\footnotetext{
${ }^{14}$ Margherita Ganeri, op. cit.

15 Giuseppe Tomasi di Lampedusa, op. cit., s. 186.
} 
WICEKRóLOWIE: bezlitosna autobiografia narodu włoskiego

i egoizmie włoskich polityków. Ta charakterystyka systemu celnie i zatrważająco dotyczy współczesnych Włoch, gdzie dekrety z mocą ustawy regulujące processo breve (tj. krótki proces), legittimo impedimento (tzw. przeszkodę prawną), legge bavaglio (tzw. ustawę kagańcową $)^{16}$ zagrażają podstawom demokracji państwa poprzez pogwałcenie zasady równości wszystkich obywateli wobec prawa. Przedkładanie własnego interesu nad interes państwa to zjawisko ogólnie znane we współczesnych Włoszech. W ten oto sposób film staje się „bezlitosną autobiografią włoskiego narodu”, zgodnie ze sloganem wymyślonym przez Antonia Di Grado na użytek kinowej kampanii promocyjnej. Nic więc dziwnego, że recenzenci wytknęli adaptacji Faenzy jej niezwykle silny wydźwięk współczesny, podejrzewając, że film został zrobiony na polityczne zamówienie. Co więcej, z tego samego powodu, został on wykluczony z konkursu Międzynarodowego Festiwalu Filmowego w Rzymie w $2007 \mathrm{roku}^{17}$. Prawdę mówiąc, aż dziwi fakt, że tym razem cenzura

${ }^{16}$ Dekret z mocą ustawy dotyczący tzw. krótkiego procesu ma na celu przyspieszenie terminu przedawnienia niektórych spraw, w które zamieszane są najważniejsze postaci włoskiej sceny politycznej. Dekret dotyczący tzw. przeszkody prawnej pozwala na maksymalnie półtoraroczne zawieszenie procesów sądowych toczących się przeciw premierowi i jego ministrom, jeśli rząd uzna, że udział w przesłuchaniach utrudniałby im sprawowanie obowiązków konstytucyjnych (por. Tomasz Bielecki, Niekaralny Silvio Berlusconi „Gazeta Wyborcza”, 12.03.2010). „Ustawa kagańcowa”, tzw. knebel, nakłada surowe kary za posługiwanie się danymi z podsłuchów (450 tys. euro grzywny dla wydawcy, miesiąc więzienia dla dziennikarza), które przeciekają do mediów, ogranicza publikację materiałów objętych tajemnicą śledztwa przed rozpoczęciem procesu sądowego (300 tys. euro kary dla wydawcy) oraz utrudnia prokuratorom zakładanie podsłuchów, zwłaszcza u parlamentarzystów i księży katolickich (por. idem, Precz z kneblem Berlusconiego , „Gazeta Wyborcza”, 10.07.2010).

${ }^{17}$ Co ciekawe, konflikt polityczny prawicy z lewicą nie przełożył się na konflikt na planie filmowym. Lando Buzzanca, odtwórca roli don Giacomo, znany ze swoich prawicowych sympatii, bardzo dobrze wspomina współpracę z Faenzą, jednym ze sztandarowych reżyserów lewicujących i na łamach „Corriere della Sera” wyraził swój żal z powodu wykluczenia filmu z konkursu przez dyrekcję Międzynarodowego Festiwalu Filmowego w Rzymie (Paolo Conti, I Vicerè della discordia, „Corriere della Sera”, 3.11.2007). 
polityczno-religijna, wciąż nad wyraz aktywna we Włoszech, nie wstrzymała realizacji tego filmu, który tak śmiało atakuje przecież podstawy kultury włoskiej: politykę, kościół oraz rodzinę ${ }^{18}$.

Film Roberta Faenzy spełnia podwójnie pozytywną funkcję we włoskiej kulturze. Z jednej strony, tworzy swego rodzaju parabolę moralną i społeczną dziejów kraju, bezlitosną satyrę na naród włoski, przedstawiającą emocje rządzące ludźmi do dzisiaj. Z drugiej strony, czyni to sięgając po zapomnianą już, a wciąż niezwykle współczesną powieść.

18 Por. wywiad z Faenzą przeprowadzony przez studentów rzymskiego uniwersytetu La Sapienza (w ramach dwuletniego projektu FantAuditel), www. youtube.com/watch?v=TMsudShQmpE (10.10.2010). 